DOI: 10.38136/jgon.666759

\title{
İntravenöz İmmünoglobulin ve Eritrosit Transfüzyonu ile Tedavi Edilen Bir Anti-C izoimmünizasyonu: Vaka Takdimi
}

\section{An Anti-C Isoimmunization Treated with Intravenous Immunoglobulin and Erythrocyte Transfusion: A Case Report}

\author{
Fatma IYIGÜN \\ Elmas YILMAZ \\ İstemi ÇELIK ${ }^{3}$ \\ Ahmet Yağmur BAȘ \\ Nihal DEMIREL ${ }^{3}$
}

(1) Orcid ID: $0000-0003-4770-4112$

(1) Orcid ID: 0000-0002-8934-3477

(1) Orcid ID: 0000-0002-2952-8154

(1) Orcid ID: 0000-0002-1329-2167

(1) Orcid ID: 0000-0003-2044-2212

${ }^{1}$ Yozgat Șehir Hastanesi- Yenidoğan Yoğun Bakım Ünitesi, Yozgat, Türkiye

${ }^{2}$ Gülhane Eğitim ve Araștırma Hastanesi, Ankara, Türkiye

${ }^{3}$ Etlik Zübeyde Hanım Kadın Hastalıkları Eğitim ve Araștırma Hastanesi Neonatoloji Kliniği, Ankara, Türkiye

\section{öz}

Yenidoğan hemolitik hastalığı (YHH) nedenleri içerisinde minör kan grubu uygunsuzluğunun önemi giderek artmaktadır. Major kan grubu uygunsuzluğu bulunmayan ve hemolitik hastalığı olan yenidoğanlarda minör kan grubu uyuşmazlığı da düşünülmelidir. Minör kan grubu uyuşmazlığı olgularında subklinik hemoliz bulgularından aktif hemoliz ve kan değişimi gerektiren yenidoğan sarılığına kadar değişkenlik gösteren tablolar görülebilir. Rh sistemi içinde yer alan $\mathrm{C}$ antijenine karşı gelişmiş anti-C antikorları hafif seyirli anemi ve hiperbilirubinemi ile seyreden izoimmünizasyona neden olur. Burada hafif- orta şiddette izoimmunizasyon gösteren, hayatının ikinci haftasında fototerapi gerektiren hiperbilirubinemi ve transfüzyon gerektiren anemisi olan bir olgu sunulmuştur.

Anahtar kelimeler: Yenidoğan, hemolitik anemi, anti-C uygunsuzluğu, intravenöz immünoglobulin

\section{Gíriş}

Minör kan grubu uygunsuzluğu yenidoğan hemolitik hastalıklarının (YHH) \%3-5'inden sorumludur. Anti-D gamaglobülinin kullanım sıklığının artması ile YHH etiyolojisinde minör kan grubu uygunsuzluğunun önemi artmıştır. Bu grupta Kell, Duffy, Kidd, MNSs ile Rh sistemi içinde bulunan E, e, C, c antijenleri bulunur. Anti-D antikorlarından sonra sıklık sırasına göre anti-E, anti-C ve anti Kell antikorları YHH nedenidirler (1). Literatürde bilinen anti-C izoimmünizasyonu olguların çoğu hafif-orta şiddette anemi ve sarılık şeklindedir (2-3). Yenidoğan hemolitik hastalığında; fototerapi, kan değişimi ve gebelikte ortaya çıkan şiddetli vakalarda ise intrauterin transfüzyona kadar giden tedavi seçenekleri vardır. İntravenöz immünglobulin (IVIG) yenidoğan dönemindeki izoimmün hemolitik anemiye bağlı kan değişi-

\section{ABSTRACT}

The importance of minor blood group incompatibility is gradually increasing among the causes of neonatal hemolytic disease. Minor blood group incompatibility should also be considered in newborns with hemolytic disease and no major blood group incompatibility. In cases of minor blood group incompatibility, presentations varying from subclinical hemolysis findings to active hemolysis and neonatal jaundice requiring exchange transfusion can be observed. Anti- $C$ antibodies developed against the $C$ antigen in the Rh system cause isoimmunization with mild anemia and hyperbilirubinemia. Here, a case with mild to moderate isoimmunization, hyperbilirubinemia requiring phototherapy and anemia requiring transfusion in the second week of his life is presented.

Key words: Neonate, hemolitic anemia, anti-C incompatibility, intravenous immunoglobulin

mi sıklığını azaltmak için kullanılabilir (4). Bu yazıda minör kan grubu $C$ uygunsuzluğu saptanan anemi ve hiperbilirubinemi ile izlenen bir olgu sunulmuştur.

\section{OLGU}

Yirmi altı yaşındaki annenin 37 gebelik haftasında dördüncü gebeliğinden dördüncü yaşayan olarak sezaryen ile hastanemizde 2500 gram ağırlığında doğan erkek bebek normal fizik muayene bulguları ile doğumdan iki gün sonra kontrol muayenesi planlanarak taburcu edildi. Doğum öncesi öyküde özellik olmadığı, anne-babanın birinci derece kuzen olduğu, yaşayan iki sağıklı kardeşinde yenidoğan döneminde sarılık öyküsü olduğu öğrenildi. Doğum sonrası on dördüncü günde gözünde akıntı yakınması ile polikliniğimize getirilen hastanın fiziksel incelemesinde cilt ve skleralarda ileri derecede sarıık dışında bulgu yoktu. 
Ensefalopati bulgusu saptanmadı. Tonusu normaldi. Göbek kordonu düşmüştü. Hasta evde anne sütü ile beslenmiş, patolojik kilo kaybı olmamış ve doğum tartısını yakalamıştı. Laboratuvar incelemelerinde serum total ve direkt bilirubin düzeyleri sırasıyla $26,8 \mathrm{mg} / \mathrm{dl}$ ve $2 \mathrm{mg} / \mathrm{dl}$, hemoglobin $10,1 \mathrm{~g} / \mathrm{dl}$, beyaz küre sayıs। $16470 / \mathrm{mm}^{3}$, trombosit sayısı $851000 / \mathrm{mm}^{3}$, kan grubu B Rh (+), direkt Coombs testi negatif olarak saptandı. Periferik kan yaymasında anizositoz, poikilositoz, fragmente eritrositler saptandı, atipik hücre görülmedi. Anne kan grubu B Rh (+) idi. Hiperbilirubinemi ve anemi nedeni ile bakılan minör kan gruplarında anne: C (-) C (+) E (+) e (+) Kell (-), bebek: C (+) c (+) E (+) e (+) Kell $(-)$ olarak saptandı. Annede indirekt Coombs testi negatif olarak sonuçlandı. Glukoz 6 fosfat dehidrogenaz enzim düzeyi ve tiroid fonksiyon testleri normal bulundu. Transfontanel ve abdominal ultrasonografileri normal olarak raporlandı. Klinik ve laboratuvar bulguları göz önüne alınarak anti-C'ye bağlı minör kan grubu uygunsuzluğuna bağlı YHH tanısı kondu. Fototerapi tedavisinin 4. saatinde total bilirubin düzeyi $20 \mathrm{mg} / \mathrm{dl}$ idi ve yoğun fototerapi devam edildi. Tedavinin 16. saatinde total bilirubin değeri $14 \mathrm{mg} /$ dl'ye düşen ancak anemisi gelişen, venöz hematokriti $\% 29,9$, hemoglobini $7 \mathrm{gr} / \mathrm{dl}$ olan hastaya $1 \mathrm{gr} / \mathrm{kg}$ IVIG verildi ve $15 \mathrm{ml} / \mathrm{kg}$ minör kan grubu uyumlu eritrosit süspansiyonu transfüze edildi. Fototerapisine aralıklı devam edilen hastanın postnatal 19. gününde bakılan rebound total bilirubini $12,2 \mathrm{mg} / \mathrm{dl}$ ve hemoglobini 13,2 gr/dl olması üzerine taburcu edildi. 3 aylık takibi süresince tekrar hiperbilirubinemi ve anemisi olmadı.

\section{TARTIŞMA}

Yenidoğanda izoimmün hemolitik aneminin en sık nedeni kan grubu uyuşmazılıklarıdır. Anti-D immunglobulin kullanımının yaygınlaşması ile Rh uygunsuzluğuna bağlı izoimmün hemolitik anemi vaka sayısı azalmaktayken minör kan grubu uygunsuzluklarının önemi artmaktadır. Minör kan grubu uygunsuzluğunda $A B O$ ve Rh grup uygunsuzluğuna benzer şekilde maternal antikorların fetüs ve yenidoğanda hemolize yol açması patogenezde rol alır. İlk antijenik uyarı ile oluşan IgM yapısında olan maternal antikorlar plasentayı geçemez ve fetüsü etkilemez. Tekrarlayan antijenik uyarılar lgG yapısında antikorlar oluşmasına ve bu antikorların titresinin artmasına yol açar. Plasentayı geçen bu antikorlar annede indirekt coombs testi pozitifliğine ve bebekte klinik şiddeti değişken hemolitik hastalığa sebep olur (2). İntrauterin dönemde fetüse geçen antikorlar hidrops fetalis ve fetal kayıp nedeni olabilir. İmmunizasyonun düşük oranda gerçekleştiği hafif vakalarda klinik bulgular doğumdan sonra hafif ve uzamış sarılık ile ortaya çıkabilmektedir (1).

$\mathrm{Rh}$ grubu antijenlerden olan $\mathrm{C}$ antijenine karşı izoimmünizasyon oluşması, genellikle yenidoğan döneminde tanınan hafif-orta anemi ile seyreder. Ağır hemoliz beklenmemekle birlikte literatürde hidrops ile seyreden ve fetal kayıp ile sonuçlanan vakalar mevcuttur (5). Byers ve ark. fetal dönemde anemi tanısı konan ve hem intrauterin transfüzyon hem de yenidoğan döneminde kan değişimi ile anemisi tedavi edilen anti-C antikorlara bağIı ağır hemoliz vakası bildirmişlerdir (6). Biberoğlu ve ark. ise hidrops fetalis saptanan anti-C izoimmünizasyon vakası tanımlamışlardır (7). Bolat ve ark. postnatal ilk günde ortaya çıkan hiperbilirubinemi ve hafif anemisi (hematokrit \%37) olan bir hastada anti-C izoimünizasyonu tanısı konularak fototerapi ve IVIG ile tedavi edildiğini bildirmişlerdir (3). Filbey ve ark. anti-C izoimmünizasyonu olan ve hafif-orta anemi şeklinde seyreden 12 vakanın hiçbirinde fototerapi ve kan değişimine gerek duyulmadığını (8), Howard ve ark. ise anti-C izoimmünizasyonu olan 15 yenidoğanın değerlendirmesinde direkt coombs testinin sadece 2 bebekte pozitif olduğunu ve bu iki olguda eşlik eden $A B O$ uygunsuzluğu da bulunduğunu bildirmişlerdir. Aynı çalışmada 15 olgudan sadece birinde fototerapi gereksinimi olan hiperbilirubinemi ile karşılaşıldığı ve transfüzyon ve kan değişimi gereksinimi olmadığı bildirilmiştir (9). Ülkemizden yapılan bir vaka takdiminde anti-C izoimmünizasyonu ile periferik kan yaymasında hemoliz görülmüş olmasına rağmen direkt coombs testi negatif olan üç olguda sadece uzamış sarılık saptanmış olup yenidoğan yoğun bakım ünitesinde yatış öyküsü ve takiplerinde tedavi gereksinimleri olmamıştır (10). Literatürde daha çok hafif-orta anemi ve uzamış sarılık şeklinde bulgu veren vakalar bildirilmekle birlikte hastamızda şiddetli hemoliz bulgularına bağıı olarak kan değişim sınırının üzerine çıkan hiperbilirubinemi, transfüzyon gerektiren anemi ve hemolizi engellemek amacıyla IViG tedavi intiyacı mevcuttu. Hastamızın özellikleri dikkate alındığında anti-C izoimmünizasyonunun beklenenden daha ciddi bulgulara yol açabileceği akılda tutulmalıdır.

Yapılan çalışmalarda minör kan grubu açısından uyuşmazık saptanan olguların sadece üçte birinde direkt coombs testi pozitifliği bulunmuştur. Direkt Coombs testi negatifliğinin uyuşmazlık olmadığını göstermediği, minör eritrosit antijenlerinin zayıf antijenik özelliklerinden kaynaklandığı düşünülmektedir (2).

Üreme çağındaki kadınlarda indirekt antikor aranması konusunda yapılmış detaylı bir çalışmada 37506 örneğin değerlendirildiği ve 615 örnekte antikor pozitifliği saptandığı ve bu antikor pozitifliği saptanan olgular içinde $C$, Kell, D ve $E$ uygunsuzluğunun sırasıyla $\% 4,9, \% 22, \% 18,4, \% 14$ ve $\% 5,8$ olduğu bildirilmiştir. (11).

Günümüzde anti-D gamaglobülin kullanımının yaygınlaşması 
kan değişimi gereksinimini azaltmıştır (4). Az sayıda gerçekleştirilen kan değişimi sırasında çeşitli komplikasyonlar görülebilmektedir (4). IVIG tedavisi kan değişimi ve anemi riskini azaltmak için kullanılabilecek tedavi seçeneklerinden biridir. $R h$ ve $A B O$ izoimmünizasyonunda IVIG ile tedavinin etkinliğini inceleyen çalışmalar değerlendirildiğinde, IVIG tedavisinin kan değişimi sıklı̆ını azalttığı bildiren yayınlar yanında (13) kan değişimi, eritrosit süspansiyonu gereksinimi ve hastanede yatış süresi üzerinde etkisi olmadığını bildiren yayınların da mevcut olduğu görülmektedir (14). Etki mekanizması tam bilinmemekle birlikte Fc reseptörüne bağlanan immunglobulinlerin retüküloendotelyal sistem aracıı̆̆ı ile gerçekleşen eritrosit yıkımını engellediği düşünülmektedir (7).

İntravenöz immunglobulin ile tedavi edilen minör kan grubu uygunsuzluğu olgusu oldukça fazla sayıda olup, $\mathrm{C}$ minör kan grubu uygunsuzluğu nedeniyle IVIG ile tedavi edilen olgular da mevcuttur $(3,7,15)$. Bolat $F$ ve ark. anti-C uygunsuzluğu olan olgularında immun hemolitik anemi ve indirekt hiperbilirubinemi saptamış ve IVIG ile tedavi uygulamış, takipte sarıııta tekrar artış olmadığını bildirilmemiştir (3). Antenatal izlemde maternal indirekt coombs testi pozitifliği ile takip edilen ve postnatal izleminde anti-C uygunsuzluğu saptanan bir olgunun IViG ile tedavi edildiği bildirilmiştir (7). Olgumuzda benzer şekilde indirekt bilirubinemi ile anemi saptandı, hiperbilirubinemi diğer olgulardan farklı olarak hayatın on dördüncü gününde izlendi ve IVIG ile tedavi edildi, takipte sarılıkta artış gözlenmedi.

Sonuç olarak bizim hastamızda olduğu gibi sarılık ve anemi ile başvuran ve hemoliz düşünülen ancak majör kan grubu uygunsuzluğu olmayan olgularda, minör kan grubu uygunsuzluğu olabileceği ve direkt coombs testinin negatif saptanabileceği hatırlanmalı, anti-C izoimmünizasyonunda kan değişimi, eritrosit süspansiyonu transfüzyonu, IVIG ve fototerapi gereksinimi olabilecek ağır hemoliz görülebileceği akılda tutulmalıdır.

\section{REFERANSLAR}

1. Luchtman-Jones L, Schwartz AL, Wilson DB: The blood and hematopoietic system: hematologic problems in the fetus and neonate. In: Fanaroff AA, Martin RJ (eds). Neonatal-Perinatal Medicine: Diseases of the Fetus and Infant (7th ed) Vol 2. St Louis: Mosby 2002;2:1194-1238.

2. Zipursky A, Bowman JM. Isoimmune hemolytic diseases. In: Nathan DG, Oski FA (eds). Hematology of Infancy and Childhood, 4th ed. Philadelphia: WB Saunders C 1993;2:44-73.

3. Bolat F, Bülbül A, Uslu S, Cömert S, Can E, Nuhoğlu A. Anti-Kell ve anti-C alloimmünizasyonu: Üç olgu sunumu. Şişli
Etfal Hastanesi Tıp Bülteni 2009;43:142-145.

4. American Academy of Pediatrics. Subcommittee on Hyperbilirubinemia Management of hyperbilirubinemia in the newborn infant 35 or more weeks of gestation. Pediatrics 2004;114:297-316.

5. Appelman Z, Lurie S, Juster A, Borenstein R. Severe hemolytic disease of the newborn due to anti-C. Int J Gynaecol Obstet 1990;33:73-75.

6. Byers BD, Gordon MC, Higby K: Severe hemolytic disease of the newborn due to anti c. Obstet Gynecol 2005;106:1180-1182.

7. Biberoğlu E, Toğrul C, Özgü Erdinç AS, Tuncer EG, Uygur D, Danışman N. Prenatal Diagnosis of Maternal-Fetal Blood Subgroup Antigen Incompatibility Due to C Antigen: A Case Report. Gynecol Obstet Reprod Med 2013;19:112-114.

8. Filbey D, Hanson U, Wesstrom $G$. The prevalence of red cell antibodies in pregnancy correlated to the outcome of the newborn. Acta Obstet Gynecol Scand, 1995;74: 687-92.

9. Howard H, Martlew V, McFadyen I, et al. Consequences for fetus and neonate of maternal red cell allo-immunisation. Arch Dis Child Fetal Neonatal Ed 1998;78:62-66.

10. Can E, Özkaya H, Meral C, Süleymanoğlu S, Aydınöz $S$, Karademir F, et al. Anti-C'ye bağlı Yenidoğanın Hemolitik Hastalığı ve Uzamış Sarıı̆ı: Üç Vaka Takdimi. Çocuk Sağlığı ve Hastalıkları Dergisi 2009; 52: 88-90.

11. Geifman-Holtzman O, Wojtowycz M, Kosmas E, Artal R. Female alloimmunization with antibodies known to cause hemolytic disease. Obstet Gynecol 1997;89:272-275.

12. Gökçe İK, Güzoğlu N, Öncel MY, Çalışıcı E, Canpolat $\mathrm{FE}$, Dilmen U. Yenidoğan Döneminde Anemi ile Semptom Veren Minör Kan Grubu (Anti-C ve Anti-E) Uygunsuzluğuna Bağlı Hemolitik Hastalık. Türkiye Çocuk Hast Derg/Turkish J Pediatr Dis / 2014;1:32-34.

13. Gottstein R, Cooke RW. Systematic review of intravenous immunoglubulin in haemolytic disease of the newborn. Arch Dis Child Fetal Neonatal Ed 2003;88:F6-F10.

14. Demirel G, Akar M, Celik IH, Erdeve Ö, Uras N, Oğuz $\mathrm{SS}$, et al. Single versus multiple dose intravenous immunoglobulin in combinated with LED phototherapy in the trearment of $A B O$ hemolytic disease in neonates. Int Hematol 2011;93:700-703.

15. Çelik ï. İkiz bebeklerde anti-e izoimmünizasyonu: Vaka takdimi. Çocuk Sağlığı ve Hastalıkları Dergisi 2014;57:2426. 